\title{
Self-Efficacy and Intensity of the Use of Social Media on Consumption Behavior: Case Study in the Economics Faculty of Yogyakarta State University
}

\author{
Nyimas Yuhanis Sartika ${ }^{1}$, Sugiharsono ${ }^{2 *}$ \\ 1,2 Universitas Negeri Yogyakarta, Indonesia \\ Inyimasyuhanissartika.2017@student.uny.ac.id, ${ }^{2}$ sugiharsono@uny.ac.id, *corresponding author
}

\begin{abstract}
This study aims to examine the effect of self-efficacy and the intensity of social media use on student consumption behaviour, both partially and simultaneously. It belongs to causal associative research with a quantitative approach. The population of this study was 476 undergraduate students batch of 2016 in the Faculty of Economics, Yogyakarta State University (YSU). A sample of 217 students was selected through a proportional cluster random sampling technique. Data were collected using questionnaires that were previously tested for validity and reliability. The data analysis technique used a multiple regression.
\end{abstract}

Keywords: consumption behavior, self-efficay, intensity of the use of social media

\section{Efikasi Diri dan Intensitas Penggunaan Media Sosial Terhadap Perilaku Konsumsi: Stadi Kasus di Fakultas Ekonomi Universitas Negeri Yogyakarta}

\begin{abstract}
Abstrak
Penelitian ini bertujuan untuk mengetahui pengaruh efikasi diri dan intensitas penggunaan media sosial terhadap perilaku konsumsi mahasiswa, baik secara parsial maupun simultan. Penelitian ini termasuk penelitian asosiatif kausal dengan pendekatan kuantitatif. Populasi penelitian ini adalah 476 mahasiswa Strata-1 Fakultas Ekonomi Universitas Negeri Yogyakarta angkatan 2016. Adapun jumlah sampel 217 mahasiswa yang diambil dengan teknik proportional cluster random sampling. Data dikumpulkan dengan kuisioner yang telah diuji validitas dan reliabilitasnya. Teknik analisis data yang digunakan adalah regresi berganda.
\end{abstract}

Kata kunci: perilaku konsumsi, efikasi diri, intensitas penggunaan media sosial

\section{INTRODUCTION}

World trade is currently growing, with many young entrepreneurs starting their businesses with more innovative products. This phenomenon makes competition among foreign producers and in Indonesia itself even tougher. As a producer, understanding consumer behavior becomes important to compete with other producers. Producers who understand their consumer behavior will be able to estimate how consumers tend to react to the information they receive, so that producer can develop appropriate marketing strategies and brands that are acceptable to their consumers. A brand owned by a producer can secure a higher market share as long as it reduces the risks associated with sales and meets certain emotional needs of consumers (Budac and Lia, 2013).

Consumers always respond or react to environmental stimuli, including responding to products offered by producers. This consumer reaction, called consumption behavior. Economists always use the assumption that humans are rational. However, Thaler (2017) argues that human rationality is limited, depending on how they adopt internal self-control 
to evaluate and manage their budgets, and predict how this will affect spending, savings, and other household behavior. The internal self-control system referred to here is selfefficacy. Self-efficacy is self-perception about how well the self can function in certain situations (Bandura, 1997). Self-efficacy is related to the belief that we have the ability to take the expected action. Self-efficacy is self-assessment, whether it can do good or bad actions, right or wrong, biased or not biased to work as required. Self-efficacy is a construct based on social cognitive theory. Human action is a reciprocal relationship between individuals, the environment, and behavior (triadic reciprocal causation). Selfefficacy plays a very large role because it can help someone in making choices, their efforts to progress, the persistence and perseverance they show in facing difficulties, and the degree of anxiety or calm they experience when they maintain tasks that cover their lives (Bandura 1986).

In addition to self-efficacy, a factor that causes varied consumption behavior is the presence of social media. The intensity of the use of social media triggers someone to consume goods or services higher. This is supported by Ramnarain and Govender's (2013) research which said that the majority $(80 \%)$ of respondents indicated that social media browsing affected their buying behavior, with $43 \%$ indicating that they had bought goods through social media more than eight times, $23 \%$ bought goods between five and eight times, $10 \%$ of the items purchased are between two and four times, and only $4 \%$ indicate that they have bought once.

The phenomenon of consumption behavior also occurs in the Faculty of Economics, Yogyakarta State University. Based on interviews with several students, most of them have a penchant for buying goods that can increase their confidence, such as gadgets, cosmetics, and branded goods at high prices. Those who are given an excess allowance, often use the money to consume beyond their educational needs. Even those of middle to lower social status, too. This indicates that the student has low self-efficacy. Even though as students of the Faculty of Economics, Yogyakarta State University they are taught the basics of economics, wherewith the existing income they can meet their needs and get maximum satisfaction. In meeting secondary and tertiary needs, students are often complacent about what is presented in the media, or experiences shared by their friends. They are tempted to go on vacation abroad even though their budget is insufficient for that. They want to go to a prestigious school because they join in with friends or just to look cool to the public. These expenses, which should have been minimized, would be difficult if they had low self-efficacy.

The rapid flow of communication technology, especially in the economic sector, also had an impact on the birth of consumptive behavior and saw the phenomena that occurred related to the influence of advertising on social media, giving many impacts to various groups of society. Teenagers as one of the groups in society, can't be separated from the influence of this consumerism, because adolescents are often targeted as a product of the company. Some of the students of the Faculty of Economics, Yogyakarta State University often imitate the trends that are developing in social media, such as Instagram. They also often use social media to buy various needs supporting their pregnancy. The more often 
they explore social media such as Instagram, Facebook, or online shopping applications, the higher they want to buy goods outside their basic needs as a student.

Based on the phenomena that have been described, researchers are encouraged to research the effect of self-efficacy and intensity of the use of social media on student consumption behavior at the Faculty of Economics, Yogyakarta State University. The results of this study are expected to be input for entrepreneurs to analyze what is needed by consumers, especially students so that the business continues to experience profits so that it will develop. In more detail, several objectives to be achieved from this study are (1) analyzing the effect of self-efficacy on student consumption behavior at the Faculty of Economics, Yogyakarta State University, (2) analyzing the influence of the intensity of the use of social media on student consumption behavior at the Faculty of Economics, Yogyakarta State University.

In this case, the theory of planned behavior (Theory of Planned Behavior) will be presented. According to the Theory of Reasoned Action (TRA) behavior is influenced by intention, while the intention is influenced by attitudes and subjective norms. This theory was further developed by Ajzen (1985) into the Theory of Planned Behavior (TPB) which is intended to predict individual behavior more specifically. The construct added to this theory is perceived behavioral control.

The attitude toward a behavior is a belief about the consequences of behavior or briefly called behavioral beliefs (behavioral beliefs) (Ajzen, 2005). Confidence relates to an individual's subjective assessment of the world around him, an individual's understanding of himself and his environment, carried out by linking certain behaviors with various benefits or losses that might be obtained if the individual does or does not do it. This theory shows that a person's desire to behave or not in an action is based on beliefs and an evaluation of the results that result from his behavior. So, someone who has the belief that the results obtained are positive, it will appear positive about the behavior, and vice versa.

Subjective norm is an individual's perception of the expectations of people who influence his life (significant others) regarding the do or not do certain behaviors. This perception is subjective, so this dimension is called subjective norms. As with attitudes toward behavior, subjective norms are also influenced by beliefs. The difference is that if attitudes toward behavior are a function of individual beliefs about behavior that will be carried out (behavioral belief), then subjective norms are functions of individual beliefs obtained from the views of others towards attitudes related to individuals (normative beliefs).

Behavioral control perception or can be called behavior control is the individual's perception of the ease or difficulty of realizing a certain behavior (Ajzen, 2005). To explain this perception of behavioral control, Ajzen distinguishes it from the locus of control or center of control proposed by Rotter $(1975 ; 1990)$. The center of control is related to individual beliefs that are relatively stable in all situations. Behavioral control perception can change depending on the situation and type of behavior to be performed. The center of control is related to an individual's beliefs about his success in doing everything, whether it depends on his own efforts or other factors outside him (Rotter, 1975). If these beliefs are 
related to specific achievements, for example, beliefs can master computer skills well, called behavioral control.

Based on the description above, consumption behavior based on the theory of perception of self-control (Theory of Planned Behavior) is formed by the attitude, toward the behavior, subjective norm, and perceived behavioral control.

According to Suryani (2008: 6) consumption behavior is the study of how individuals, groups and organizations and processes are undertaken to select, secure, use and stop products, services, experiences or ideas to satisfy their needs and their impact on consumers and society. Nugroho (2015: 2) states that consumer behavior is an action that is directly involved in getting, consuming, and consuming products or services, including the decision process that precedes and follows this action. Khan (2006: 4) states that consumer behavior can be defined as the decision-making process and physical activity involved in acquiring, evaluating, using and disposing of goods and services. So, it can be concluded that consumer behavior is the behavior of a consumer both individually or the wider community to carry out consumption actions that are always changing and moving all the time.

The indicators used in this study are intentions, attitudes, subjective norms, and behavioral control. The indicators in this study were adopted from the theory developed by Ajzen (1985), namely the Theory of Planned Behavior (TPB). Taking indicators in this study adjusted to the conditions on the ground.

The concept of self-efficacy was introduced by Bandura (1997). He defines that selfefficacy is an individual's beliefs about his ability to perform tasks or actions needed to achieve certain results or actions needed to achieve certain results. According to Baron \& Byrne (2008), self-efficacy is one's evaluation of one's ability to carry out a task of achieving goals and overcoming obstacles. Gibson et.al (2012: 159) argues that selfefficacy is the belief that someone can do something in a certain situation quite deep.

Based on the description above, self-efficacy can be interpreted as an individual's confidence in the ability possessed in dealing with or completing a task by the objectives to be achieved. The indicators used in this study are Generality, Magnitude, and Strength. The indicators used in this study were adopted from the theory put forward by Bandura (1997). The study only took a few indicators because it adjusts to the research subject.

Intensity according to Azwar (1998) is the strength or depth of attitude towards something. Santrock (2008) Intensity can be said as a form of attention and interest based on the quality and quantity designated by the individual. Furthermore, the intensity or the number of activities carried out can be seen from the frequency.

According to Gunelius (2011), Social media is a communication tool used to interact (conversation, involvement, and participation). Social media can also be used to build relationships and social interactions (Safko, 2010). The use of social media is often used as a communication tool between sellers and buyers (McCann \& Barlow, 2010).

The intensity of the use of social media based on quality is a form of attention and interest carried out by someone in using social media and emotional feelings in which are involved in the interests and appreciation that arise when accessing one's social media 
while based on the quantity or intensity of the number of activities carried out can be seen from the frequency. Indicators to measure the intensity of the use of social media in this study are attention, appreciation, duration, and frequency in using social media.

Based on the problems discussed above, we can discuss the factors that influence student consumption behavior at the Faculty of Economics, Yogyakarta State University. The author aims to find evidence about self-efficacy and the intensity of the use of social media affect student consumption behavior.

\section{METHOD}

This study uses multiple regression methods with three variables (self-efficacy, the intensity of use of social media, and student consumption behavior). The dependent variable in this study is consumption behavior. The independent variables in this study are self-efficacy and intensity of use of social media

The population in this study was the S-1 batch of the Faculty of Economics, Yogyakarta State University, 2016. The Faculty of Economics, Yogyakarta State University, 2016 has a coverage of 476 students from 5 majors. From this population, the authors took students to take research samples. The sample in this study was determined by random sampling technique. Samples obtained amounted to 217 S-1 Faculty of Economics. After obtaining the number of research samples, the next step is to determine the number of samples in the sub-population using proportional cluster random sampling, which is taking the sample by taking into account the proportion of the number of subpopulations (Appendix 1).

Data were collected using a questionnaire instrument that was distributed directly to respondents. The research questionnaire was divided into three parts. The first part is to measure student self-efficacy. The second part is to measure the intensity of the use of social media on students and the third part is to measure the consumption behavior of students.

Self-efficacy is measured by giving 9 statements, while the intensity of the use of social media 10 statements and consumer behavior is measured by giving 10 statements (Appendix 2). The statement was assessed with a Likert scale that has four scales, namely scale 4 (always), scale 3 (often), scale 2 (rare), and scale 1 (never).

Validity and reliability tests were conducted in this study. The research questionnaire was distributed to 88 respondents. Validity test in this study uses the Confirmatory Factor Analysis (CFA). The validity test results show the value of the Kaiser-Meyer-Olkin Measure (KMO) Measure of Sampling Adequacy is greater than 0.50, which is 0.560 , and then the item is declared valid if the Loading Factor value is greater than 0.5 . There is 1 item invalid statement from 29 items presented, because it has a value of $0.438<0.50$. As for the reliability test, the instrument is declared reliable if the Cronbach's Alpha value is greater than 0.6. The reliable test results showed that the Cronbach's Alpha value on the self-efficacy variable was 0.806 , the intensity of using social media was 0.685 , and the consumption behavior was 0.772 greater than 0.5 (Appendix 3). 
Before entering the multiple regression test stage, a classic test will be performed first. First, the normality test uses the Kolmogorov-Smirnov (K-S) test. The data of this study was normal because it has an Asymp value. Sig. (2-tailed) 0.137> 0.05; Second, the linearity test by looking at the value of Deviation from Linearity. Linearity test results showed that the self-efficacy variable was 0.211 and the intensity variable of social media use was 0.803 , greater than 0.05 , which means that all independent and dependent variables had a linear relationship. Third, multicollinearity test by looking at VIF values. The results of the multicollinearity test showed that the self-efficacy variable was 1,136 and the intensity of social media use was 1,110 less than 10, which meant that there was no multicollinearity between the independent and dependent variables. After the classic test, and all the requirements are met, it will proceed to the multiple regression test stage. (Appendix 4).

Multiple regression tests were performed using SPSS 23 Software to see the effect between independent variables (self-efficacy and intensity of use of social media) on the dependent variable (consumption behavior). The multiple regression equations used in this study are:

$$
\mathrm{Y}=\alpha+\mathrm{b} 1 X 1+\mathrm{b} 2 X 2+e
$$

Information:

$$
\begin{aligned}
& \mathrm{Y}=\text { Consumption Behavior } \\
& \mathrm{X} 1=\text { Self-Efficacy } \\
& \mathrm{X} 2=\text { Intensity of Use of Social Media } \\
& \mathrm{b}=\text { Regression Coefficient } \\
& \alpha \quad=\text { Constant } \\
& \mathrm{e}=\text { error }
\end{aligned}
$$

\section{FINDING AND DISCUSSION}

The results of multiple regression tests showed a $\mathrm{F}$ count of 47,762 greater than a $\mathrm{F}$ table of 2.65 at a significant level of $5 \%$ (Table1),

Table 1. The Results of the Influence of Independent Variables On the Dependent Variable Simultaneously

\begin{tabular}{cccccc}
\hline Variable & $\begin{array}{c}\text { Unstandardized } \\
\text { Coefficients } \\
\text { Beta }\end{array}$ & $\mathbf{t}$ & $\begin{array}{c}\text { Adjusted R } \\
\text { Square }\end{array}$ & F & Sig \\
\hline Constant & $-6,380$ & $-2,766$ & & 79,411 &, 000 \\
Self-Efficacy & 0,707 & 9,635 & 0,528 & &, 002 \\
$\begin{array}{l}\text { Intensity of Use } \\
\text { of Social Media }\end{array}$ & 0,362 & 5,213 & &
\end{tabular}

and an $\mathrm{R}$ value of 0.727 (Table 2). These results provide the conclusion that simultaneously there is an influence of self-efficacy and the intensity of the use of social media on consumption behavior by $72.7 \%$. 
Table 2. Model Summary

\begin{tabular}{ccccc}
\hline Model & $\mathrm{R}$ & $\mathrm{R}$ Square & Sum of Square & $\begin{array}{c}\text { Std. Error of the } \\
\text { Estimate }\end{array}$ \\
\hline 1 & 0,727 & 0,528 & 0,521 & 5,393 \\
\hline
\end{tabular}

In addition to seeing the effect of independent variables on being bound simultaneously, researchers also looked at partially. In the self-efficacy variable, sig. amounted to $0,000<0.05$, and the value of Standardized Coefficients Beta was 0,628 (Table 3). These results indicate that there is an effect of self-efficacy on consumption behavior by $62,8 \%$.

On the variable of the increasing use of social media, the value of sig. of $0,000<0.05$, and the Beta Standard Coefficient of 0.442 (Table 3). The results of this study indicate there is an influence of the use of social media on consumption use by $44.2 \%$

Table 3. The Results of the Influence of Independent Variables On Partially Dependent Variables

\begin{tabular}{lcccccc}
\hline \multirow{2}{*}{ Model } & \multicolumn{2}{c}{$\begin{array}{c}\text { Unstandardized } \\
\text { Coefficients }\end{array}$} & $\begin{array}{c}\text { Standardized } \\
\text { Coefficients }\end{array}$ & \multirow{2}{*}{$\mathrm{t}$} & \multirow{2}{*}{ Sig. } \\
\cline { 2 - 5 } & $\mathrm{B}$ & Std. Error & Beta & & \\
\hline $\begin{array}{l}\text { Self-efficacy } \\
\begin{array}{l}\text { Intensity of Use of Social } \\
\text { Media }\end{array}\end{array}$ & 0,906 & 0,077 & 0,628 & 11,826 & 0,000 \\
\hline
\end{tabular}

The following research paradigms are based on the results above:

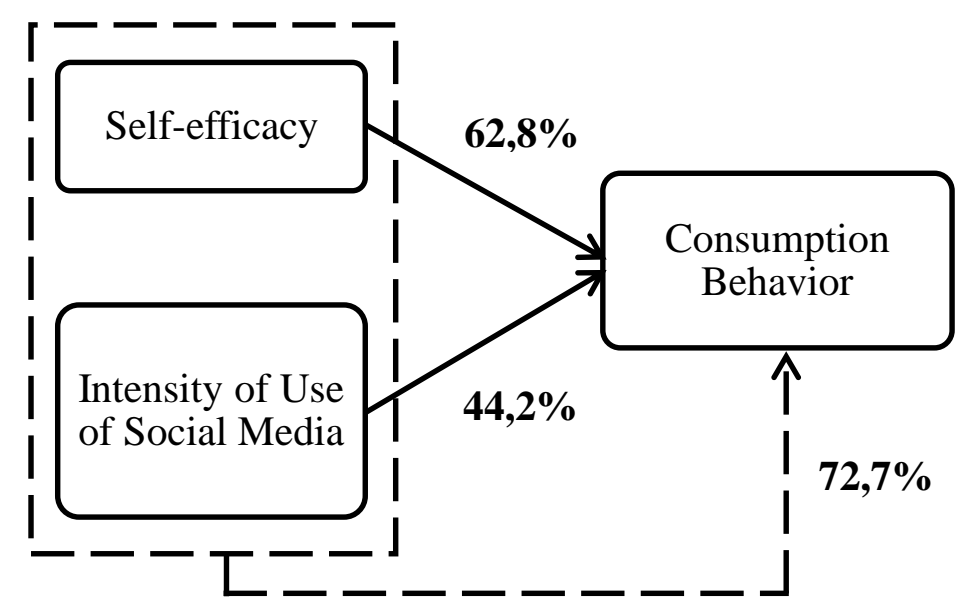

Information:

Figure 1. Research Paradigm

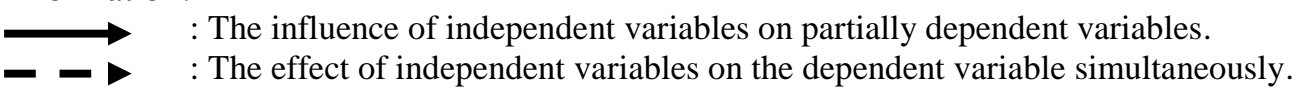

Theory of Planned Behavior (TPB) revealed by Ajzen (2005) describes self-control as part of the formation of behavior, and the closest approach to self-control is the selfefficacy of one's belief in doing something. Self-efficacy has been shown to play an 
important role in the process of self-regulation (Caprara, 2006). Self-efficacy plays an important role in the process of self-regulation, both in the fields of learning, sports work, health, social welfare, and social adjustment (Bandura, 1997; 2001). Students who have high self-efficacy, they will be able to control themselves in consuming an item/service. However, the results of the study showed that although their self-efficacy was classified as moderate, it was able to influence their consumption behavior.

Self-efficacy in this study was measured based on three indicators, namely, generality which means the confidence of students in dealing with various situations in the decision making process. Those who have high self-efficacy tend to behave positively, they have the desire to succeed, and are goal-oriented. Even in consuming a product / service, those who have self-efficacy will find out in more detail and be able to identify information related to the product / service they will consume. According to Bandura (2001), selfefficacy beliefs are the basis of humans, they believe they can exercise control over their own functions and over environmental events, they have a little extra strength to act or survive in the face of adversity; the magnitude means the students' confidence that their behavior influences what happens to them. Their desire to succeed makes them identify information related to products / services, so that the decisions they make now do not have much adverse effects in the future. Influencing how people think about future performance, self-efficacy is considered to play a central role in self-regulation through setting goals and outcome expectations (Bandura and Locke, 2003); and strength, which means students' confidence in the decisions they have made. Those who have a strong belief in their ability to do something, and do it on an ongoing basis will produce the expected outcomes (Rohmawati, 2014).

This indicator, the same as used by Garlin \& Robyn (2002), even though they use different terms, they have the same meaning. Their research say consumption behavior is formed through three categories, first evaluating products, using products and selfregulation. Consumer behavior is reflected in the way they identify information as a result of their performance, including economic results such as "best prices", "best deals", "maximum benefits" and psychological results such as "pleasure", "image defense", "pleasure and feel better". And this result will increase knowledge, reduce risk, reduce choice and evaluate.

Based on the results of descriptive data processing shows that self-efficacy with a sample of 217 students of the Faculty of Economics Yogyakarta State University class of 2016 , as many as 35 students (16.1\%) have a high category of self-efficacy value, as many as 155 students ( $71.4 \%$ ) have the value of efficacy self-moderate category, and as many as 27 students $(12.4 \%)$ had low category efficacy. These results indicate that the majority of students of the Faculty of Economics, Yogyakarta State University 2016 batch have selfefficacy tendencies of the category of "medium".

Self-efficacy of students with medium category is able to influence consumption behavior by $62.8 \%$. The cause of the medium self-efficacy of students of the Faculty of Economics of Yogyakarta State University (YSU) is their lack of consistency in behavior, where even though they know which should be prioritized, students are still often tempted 
to keep up with the demands of the times. They are more vulnerable to stress and dysfunction because of the demands of the new environment and the considerable biopsychosocial changes they experience in this phase of life (Bandura, 1995; 1997; Flammer, 1995; Schneewind, 1995). Some decisions also sometimes have significant negative results such as unused products, inability to complete transactions, and lack of satisfaction. Experience, has always been a consideration of consumers in making their consumption decisions, how they regulate their behavior (Garlin \& Robyn, 2002).

Self-efficacy that is owned by someone is not immediately formed just like that, even though they have it, but this must continue to be trained and directed and there is continuity to continue to do so. The role of education here is very necessary, where they play a role in the formation of individual characters, especially students. The need to be studied more closely related to learning materials in the classroom and addressed in real life. For example, the need for lecturers to link priority scale materials directly to choices that make it difficult for students to distinguish which priority scale they must determine in consuming a product such as skincare, novels, textbooks, to the use of gadgets that encourage them to be seen good in the eyes of the community. Give them directions, that expensive things are not always good, and cheap things are not always bad. Give understanding to them to always take notes or make a list related to their priority scale. The campus can also make a regular budget to hold public lectures / seminars with the themes of self-management, priorities and entrepreneurship that are felt to be very necessary for children of this millennial generation. Likewise, the relationship between the intensity of social media use and consumption behavior will be discussed in this study.

Intensity in this study is measured based on four indicators, namely Attention, is the student's interest in activities that are in accordance with their interests and will be far more intense and intensive compared to other activities that do not cause particular interest. Someone has special attention when accessing social media that they enjoy, so that the person can enjoy activities while accessing; Appreciation, is an understanding and absorption of information on the students' efforts to understand, enjoy, appreciate and save the presentation of information and experience gained as individual knowledge. Students like to imitate, practice and even be influenced by things or information contained in social media in real life; Duration, is the length of time lapse, time span or length of time something lasts. Often when using social media students become time conscious because they enjoy using it too much; and Frequency, is the number of repetition of behavior or behavior that is carried out repeatedly whether intentional or unintentional. Often because they enjoy using social media, students tend not to be separated from their use, so they repeatedly open social media sites that are popular.

Social media has enjoyed tremendous success in terms of usage, the development of social media has led to a paradigm shift about how people are connected and communicating with each other. Individuals are now more actively seeking information on social media than mass media (Lee, 2013). Thoumrungroje (2014) said the intensity of the use of social media affects consumption behavior directly or indirectly through Electronic Word of Mouth (EWOM). Social media is an effective tool for capturing 
consumer demand for products that are trending. In line with research related to the intensity of the use of social media and peer influence (Mursial, 2012).

Intensity of the use of social media with a sample of 217 students of the Faculty of Economics, Yogyakarta State University class of 2016, as many as 41 students $(18.9 \%)$ have a high intensity value of the use of social media, as many as 154 students (71\%) have grades the intensity of social media usage was in the moderate category, and as many as 22 students (10.1\%) had the intensity of the use of social media in the low category. These results indicate that the majority of students of the Faculty of Economics, Yogyakarta State University 2016 have the intensity of the use of social media tendency of the category of "medium".

The intensity of the use of social media that can influence consumer behavior is $44.2 \%$. Although, it does not have a big enough effect, but it shows the relationship between the intensity of social media usage and consumption behavior. Technological developments, make students spend most of their time using social media. This became possible that caused students of the Faculty of Economics, Yogyakarta State University (YSU) into the medium category in the use of social media. If this continues without restrictions on usage, it could put the intensity of their use of social media at a high category. Loroz \& Helgeson (2013) and Mittal (2006) products and brands used by consumers to describe their identities. So consumers often buy goods to satisfy themselves. Moreover, with the use of social media among students. This increase in consumption behavior will have a bad impact in the future, such as reducing the level of welfare because it cannot regulate expenditure and income.

Technological developments, forcing policy makers to revise several policies, for example policies in the use of social media. Technological developments also force us to enter an era of change or what is known as disruption. Manufacturers see great opportunities with the presence of social media, they can reduce marketing costs and get more customers without being bound by time and space. Nearly every community has a smartphone, and almost all of them solve problems through it. For example, they can buy plane tickets, trains, hotels and even their daily needs by capitalizing "online" and skating on social media and special applications buying and selling. This change forced policy makers, educators, and parents at home to understand in advance what was happening in the field and how to minimize the adverse effects of using social media and how to convey this to children including students. Students or individuals, whoever it is is very common to do things after hearing the word "no" or "no", this has become human nature. Instead of using the word prohibition, you should give direction and understanding. For example, parents at home can control the use of gadgets, not only for children but also for parents. Parents can teach children to be wise in accessing social media. At school, teachers can link the material with this change. I also suggest to teach priority scale to children from an early age. 


\section{CONCLUSION}

The results of this study found that self-efficacy and intensity of social media use affect the consumption behavior of students at the Faculty of Economics, Yogyakarta State University. Self-efficacy and intensity of use of social media on the consumption behavior of students at the Faculty of Economics, Yogyakarta State University has a partial and simultaneous influence.

Student consumption behavior can be predicted by considering the student's selfefficacy and the intensity of the use of social media. Self-efficacy possessed by students is able to make them regulate themselves and eventually will form a behavior one of which is consumption behavior. Social media is not only used as a communication tool but also used by students to find the information they need. Some students first filter the information they get, so that not every student who uses social media intensively will behave irrationally in consumption.

Low student self-efficacy must be increased by providing education related to determining priority scale in buying goods. The high intensity of the use of social media must be reduced by providing education by conveying through economic basics related to how to filter product information advertised through social media.

\section{ACKNOWLEDGEMENT}

Sincerely, the researchers thank the lecturers who have guided the authors on a regular basis. Also, thanks to colleagues who have provided constructive encouragement and criticism. So that this article can be completed correctly and on time.

\section{REFERENCES}

Ajzen, I. (1985). From Intentions to Actions: A Theory of Planned Behavior. In J. Kuhl, \& J. Beckman, Action Control: From Cognition to Behavior. Germany: Springer.

Ajzen, I. (2005). Attitude, Personality and Behavior. Berkshire, UK: Open University PressMcGraw Hill Education.

Azwar, S. (1998). Sikap Manusia: Teori dan Pengukuran. Yogyakarta: Pustaka Pelajar.

Bandura, A. (1986). Social Foundation of Thought and Action: A social Cognitive Theory. New Jersey: Prentice-Hall.

Bandura, A. (1995). Self-Efficacy in Changing Societies. New York: Cambridge University Press.

Bandura, A. (1997). Self-Efficacy: The Exercise of Control. New York: W.H Freeman and Company.

Bandura, A. (2001). Social Cognitive Theory: An Agentic Perspective. Annual Review of Psychology, Vol 52, No. 1, 1-26.

Bandura, A., \& Locke, E. A. (2003). Negative Self-Efficacy and Goal Effects Revisited. Journal of Applied Psycology, Vol 88, No. 1, 87-99. 
Baron, R. A., \& Byrne, D. (2008). Psikologi Sosial (Terjemahan Ratna Djuwita, et.al. Jakarta: Erlangga.

Budac, C., \& Baltador, L. (2013). The Value of Brand Equity. Procedia Economics and Finance, Vol 6, 444-448.

Flammer, A. (1995). Developmental Analysis of Control Beliefs. In A. Bandura, In Selfefficacy in Changing Societies (pp. 69-113). New York: Cambridge University Press.

Garlin, F., \& Denholm, R. M. (2002). Exploring the Sources of Self-Efficacy in Consumer Behavior. Asia Pacific Advances in Consumer Research, Vol 5.

Gibson, J. L., Donnelly Jr, J. S., Ivancevich, J. M., \& Konopaske, R. (2003). Organizations: Behavior, Structure and Processes. New York: McGraw-Hill.

Gunelius, S. (2011). 30-Minute Social Media Marketing. United States: McGraw-Hill Companies.

Lee, E. (2013). Impacts of Social Media on Consumer Behavior. Turku University of Applied Sciences International Business, Bachelor of Business Administration.

Loroz, P. S., \& Helgeson, J. G. (2013). Boomers and their Babies: An Exploratory Study Comparing Psychological Profiles and Advertising Appeal Effectiveness Across Two Generations. Journal of Marketing Theory and Practice, Vol 21 (3), 289-306.

McCann, M., \& Barlow, A. (2015). Use and measurement of social media for SMEs. Journal of Small Business and Enterprise Development, 273-287.

Mittal, B. (2006). I, Me, And Mine-How Products Become Consumers' Extended Selves. Journal of Consumer Behaviour, Vol 5 (6).

Nobel, The Committee for the Prize in Economic Sciences in Memory of Alfred. (2017). Richard H. Thaler: Integrating Economics with Psychology. The Royal Swedish Academy of Sciences.

Nugroho. (2015). Perilaku Konsumen. Jakarta: Prenadamedia Group.

Ramnarain, Y., \& Govender, K. K. (2013). Social Media Browsing and Consumer Behaviour: Exploring the Youth Market. African Journal of Business Management, Vol. 7 (18), 1885-1893.

Rohmawati, E. (2014). Analisis Pengaruh Iklim Etika Organisasi dan Efikasi Diri terhadap Keinginan berpindah kerja dengan Kepuasan Kerja sebagai Variabel Pemediasi. Yogyakarta: Universitas Gadjah Mada.

Rotter, J. B. (1975). Some problems and misconceptions related to the construct of internal versus external control of reinforcement. Journal of Consulting and Clinical Psychology, Vol 43, 56-67.

Rotter, J. B. (1990). Internal vs. external control of reinforcement: A case history of a Variable. American Psychologist, Vol 45 (4), 489-493. 
Safko, J. L. (2010). The Social Media Bible: Tactics, Tools, and Strategies for Business Success .

Chicago: John Wiley and Sons Inc.

Santrock, J. W. (2008). Psikologi Pendidikan (Terjemahan Tri Wibowo B.S). Jakarta: Kencana.

Schneewind, K. A. (1995). Impact of Family Processes on Control Beliefs. . In A. Bandura, In Self-efficacy in Changing Societies (pp. 114-148). New York: Cambridge University.

Suryani. (2008). Perilaku Konsumen: Implikasi pada Strategi Pemasaran. Yogtakarta: Graha Ilmu.

Thoumrungroje, A. (2014). The Influence of Social Media Intensity and EWOM on Conspicuous Consumption. Social and Behavioral Sciences, Vol. 148, 7-15.

\section{APPENDIX}

\section{Appendix 1}

The Number of Research Samples S1 Faculty of Economics Batch 2016

\begin{tabular}{clc}
\hline No & \multicolumn{1}{c}{ Majors } & $\begin{array}{c}\text { Number of } \\
\text { Respondents }\end{array}$ \\
\hline 1. & Office Administration Education - S1 & 39 \\
2. & Accounting Education - S1 & 39 \\
3. & Economic Education - S1 & 33 \\
4. & Management - S1 & 53 \\
5. & Accounting - S1 & Total
\end{tabular}

\section{Appendix 2}

\section{Research Instrument Grid}

\begin{tabular}{|c|c|c|}
\hline Variable & Indicator & Statement \\
\hline \multirow{7}{*}{ Self-efficacy } & 1. Strengh & 1. Even though it was a job that was too \\
\hline & & $\begin{array}{l}\text { 2. I refuse to learn new things if they find it } \\
\text { difficult to do. }\end{array}$ \\
\hline & & 3. If I face new things, I still try to finish the job. \\
\hline & 2. Magnitude & $\begin{array}{l}\text { 4. When I decide to do something, I will } \\
\text { immediately finish it. }\end{array}$ \\
\hline & & $\begin{array}{l}\text { 5. Even though I didn't finish my work, I would } \\
\text { still finish it. }\end{array}$ \\
\hline & & $\begin{array}{l}\text { 6. If I make a plan, I'm sure that I will finish it } \\
\text { well. }\end{array}$ \\
\hline & 3. Generality & $\begin{array}{l}\text { 7. I can handle problems that occur beyond my } \\
\text { expectations. }\end{array}$ \\
\hline
\end{tabular}




\begin{tabular}{|c|c|c|}
\hline Variable & Indicator & Statement \\
\hline & & $\begin{array}{l}\text { 8. I'm not sure about my ability to do anything. } \\
\text { 9. I felt I was able to deal with all the problems } \\
\text { that came with lectures }\end{array}$ \\
\hline \multirow{4}{*}{$\begin{array}{l}\text { The Intensity } \\
\text { of The Use of } \\
\text { Social Media }\end{array}$} & 1. Attention & $\begin{array}{l}\text { 1. I use Instagram because of the many features I } \\
\text { like. } \\
\text { 2. I enjoy activities when accessing Instagram. } \\
\text { 3. My task is forgotten when I have accessed } \\
\text { Instagram that I enjoy doing. }\end{array}$ \\
\hline & 2. Appreciation & $\begin{array}{l}\text { 4. I use Instagram because of the many features I } \\
\text { like. } \\
\text { 5. I mimic the fashion styles of people I know on } \\
\text { Instagram. } \\
\text { 6. I bought things because of an advertisement } \\
\text { that I encountered on Instagram. }\end{array}$ \\
\hline & 3. Duration & $\begin{array}{l}\text { 7. Within a day I can use Instagram more than } 3 \\
\text { hours. } \\
\text { 8. Within a day I use Instagram less than } 3 \text { hours. }\end{array}$ \\
\hline & 4. Frequency & $\begin{array}{l}\text { 9. I use Instagram } 1 \text { to } 4 \text { times a day. } \\
\text { 10. I use Instagram more than } 4 \text { times a day. }\end{array}$ \\
\hline \multirow{6}{*}{$\begin{array}{l}\text { Consumer } \\
\text { Behavior }\end{array}$} & 1. Intention & $\begin{array}{l}\text { 1. I only buy things that are well-known brands. } \\
\text { 2. I would not buy the item, if it were not from a } \\
\text { well-known brand. }\end{array}$ \\
\hline & 2. Attitude & $\begin{array}{l}\text { 3. I bought branded goods because I imitated my } \\
\text { friend even though I didn't know the quality of } \\
\text { the product }\end{array}$ \\
\hline & & $\begin{array}{l}\text { 4. I bought branded goods because I copied the } \\
\text { artists I often see on TV. }\end{array}$ \\
\hline & & 5. I bought a brand name to get a compliment. \\
\hline & 3. Subjective Norms & $\begin{array}{l}\text { 6. I prefer buying goods at Traditional Markets. } \\
\text { 7. I prefer buying goods at the Mall / } \\
\text { Supermarket. }\end{array}$ \\
\hline & 4. Behavioral Control & $\begin{array}{l}\text { 8. I only buy printed books according to my } \\
\text { educational needs. } \\
\text { 9. I bought things that I could use for a long time. } \\
\text { 10.I buy things according to my finances. }\end{array}$ \\
\hline
\end{tabular}

\section{Appendix 3}

KMO and Bartlett's Test

\begin{tabular}{clr}
\hline \multicolumn{2}{l}{ Kaiser-Meyer-Olkin Measure of Sampling Adequacy } & 0,560 \\
\hline \multirow{2}{*}{ Bartlett's Test of } & Approx. Chi-Square & 2225.223 \\
Sphericity & Df & 741 \\
& Sig & 0.000 \\
\hline
\end{tabular}


Hasil Uji Reliabilitas

\begin{tabular}{lccc}
\hline \multicolumn{1}{c}{ Variable } & $\begin{array}{c}\text { Number of } \\
\text { Items }\end{array}$ & $\begin{array}{c}\text { Cronbach's } \\
\text { Alpha }\end{array}$ & Description \\
\hline Self-efficacy & 8 & 0,806 & Baik \\
Intensity of Use of Social Media & 10 & 0,685 & Baik \\
Consumption Behavior & 10 & 0,772 & Baik \\
\hline
\end{tabular}

\section{Appendix 4}

\section{Normality test}

One-Sample Kolmogorov-Smirnov Test

\begin{tabular}{lr}
\hline & Unstandardized Residual \\
\hline N & 217 \\
Kolmogorov-Smirnov Z & 1,158 \\
Asymp. Sig. (2-tailed) &, 137 \\
\hline
\end{tabular}

\section{Linearity Test}

Variabel

\begin{tabular}{ll}
\hline Self-efficacy & 0,211 \\
Intensity of Use of Social Media & 0,803
\end{tabular}

Dependent Variable: Consumption Behavior

3. Multicollinearity Test

\begin{tabular}{lcc}
\hline Model & \multicolumn{2}{c}{ Collinearity Statistics } \\
& Tolerance & VIF \\
\hline Self-efficacy & 0,880 & 1,136 \\
Intensity of Use of Social Media & 0,901 & 1,110 \\
\hline
\end{tabular}

